\title{
DETERMINANTS OF THE ISLAMIC SOCIAL REPORTING DISCLOSURE
}

\author{
Uun Sunarsih $^{1}$, Ferdiyansyah ${ }^{2}$
}

\begin{abstract}
Determinants of the Islamic Social Reportin Disclosure. The issue of corporate responsibility was a warm up for discussion. This study aimed to analyze the influence of company issuing sukuk, size, and profitability on the disclosure of Islamic Social Reporting. This study uses secondary data obtained through the site www.bapepam.go.id and www.idx.co.id by using purposive sampling. The results showed that only size that affect the disclosure of ISR, so the larger the total assets of the greater disclosure of Islamic Social Reporting. Sukuk issuance has no effect because the ownership structure of companies in Asia, including Indonesia tends to family ownership concentration. Profitability has no effect because the company has a perspective that is different to the Islamic Social Reporting.
\end{abstract}

Keywords: Islamic social reporting, Sukuk, company size, profitability

\begin{abstract}
Abstrak. Determinan atas pengungkapan Islamic Social Reporting. Isu mengenai tanggung jawab perusahaan sedang hangat untuk didiskusikan. Penelitian ini bertujuan untuk menganalisis pengaruh perusahaan yang menerbitkan sukuk, size, dan profitabilitas terhadap pengungkapan Islamic Social Reporting. Penelitian ini menggunakan data sekunder diperoleh melalui situs www.bapepam.go.id dan www.idx.co.id dengan menggunakan purposive sampling. Hasil penelitian menunjukkan bahwa hanya size yang berpengaruh terhadap pengungkapan ISR, sehingga semakin besar total asset semakin besar pengungkapan Islamic Social Reporting. Penerbitan sukuk tidak berpengaruh karena struktur kepemilikan perusahaan di Asia, termasuk Indonesia cenderung family ownership concentration. Profitabilitas tidak berpengaruh karena perusahaan memiliki cara pandang yang berbeda-beda terhadap Islamic Social Reporting.
\end{abstract}

Kata kunci: Islamic social reporting, Sukuk, ukuran perusahaan, profitabilitas 


\section{Introduction}

Corporate social responsibility (CSR) is currently in the spotlight for the company in its business. Therefore, companies are obliged to carry out CSR. The obligation to make CSR is supported by the government through legislation that has been set in the Limited Liability Company Act No. 40 of 2007. The concept of CSR is not only growing in companies that non-Islamic, but also thrives on companies which are based on Islamic principles. CSR in Islam is not something new. Islam commands to his people to maintain the natural (Q.S. Al-Araf: 56) and recommends to have properties generous to the people that need through the door alms (Q.S. AT-Taqabun: 16). Objectives established companies in Islam is to provide benefit for all parties, not only the parties directly involved with the company, but also those who are not directly involved with the company (Triyuwono, 2012).

Islam regulates human life is not only related to human relationship with God, but also regulates the relationship between humans. Therefore, man's relationship with God and man's relationship to man can not be separated in living this life. During the measurement of CSR that is used in the company, which is based on sharia is based on the Global Reporting Initiative Index (GRI). The measurement is certainly not appropriate for a company that is recognized as an issuer of sharia and found to comply with Islamic law should disclose information that it operates according to Islamic law (Haniffa, 2002). GRI index has not described the principles of Islam as yet revealed the liberation of the elements of usury, gharar, and transactions that are forbidden by Islam. As with the ISR is the development of social responsibility disclosure therein according to Islamic principles.

Othman, et al. (2009) developed an index of disclosure relevant to the things that was mentioned earlier in the ISR Index. ISR was first proposed by Haniffa (2002) and then developed more extensively by Othman et al. (2009) in Malaysia. Haniffa (2002) revealed that the limitations of conventional social reporting so that he put forward a conceptual framework based on the provisions of sharia ISR that not only help make decisions for the Muslims but also to assist companies in fulfilling the obligations towards Allah and society.

Index ISR is a measure of the conduct of the CSR Islamic banking which contains a compilation of items of standard CSR set by AAOIFI (Accounting and Auditing Organization for Islamic Financial Institutions), which was then further developed by the researchers regarding the items of CSR that should be disclosed by an entity Islam (Othman et al., 2009). This is in accordance with the entity Islam to disclose matters relating to the principles of Islam as a transaction that is 
free from elements of usury, speculation and gharar and reveal the zakat, the status of compliance with sharia as well as social aspects such as sodaqoh, waqof, qardh hassan, up to the disclosure of worship in a corporate environment.

Ideally, it is the company which operates the sharia in carrying out its social responsibility to use appropriate indicator to the ISR. In fact, Islamic banking is still using CSR indicators of GRI guidelines (the interview with one of the managers BSM). Research on the ISR is still fairly small and mostly done in Islamic banking. To that end, researchers are motivated to perform ISR research conducted by issuers included in the List of Islamic Securities (DES). Based on this background, the research questions are: (1) Is the company issuing the sukuk affect the disclosure of ISR? (2) Is the size of the company affect the disclosure of ISR? (3) Is the effect on the profitability of the disclosure ISR? This study aims to determine the effect of company issuing sukuk, company size and profitability of the disclosure of ISR.

\section{Literature Review}

Agency theory has the view that in a company there are two parties have different interests, namely the principal and manager. Jensen \& Meckling (1976) stated that an agency relationship is a contract between the manager and the investor. Both parties have different interests, so it is likely there will be a conflict. Conflict occurs possible because the agent did not act in accordance with the interests of the principal, and this will lead to cost the agency.

Companies in the running operations must be ensured that it has fulfilled the norms upheld by the company and ensure that a party outside the company can receive the company's activities. This is consistent with the theory of legitimacy. O'Donovan (2015) stated that the legitimacy of the organization may be accepted as something given to the company and the community something to be sought or expected by the company from the public. So that legitimacy has benefits in supporting the survival of the company.

The Company is an organization that has the responsibility, not only to shareholders only, but also to the stakeholders. Freeman \& Vea (2001) defines stakeholders are individuals and groups who have a legitimate claim on the organization to Participate in the Decision making process simply because they are affected by the organization practices, policies and actions. The stakeholder of the company is not only the parties directly involved with the company, but the parties are not involved in all stakeholders who should be considered by the company (Triyuwono, 2012). If the company does not pay attention to stakeholders, it is certain that the company will be protests and condemnations from the environment surrounding the company. 
Islam is a comprehensive and universal to govern all aspects of human life on earth. Hossain et.al. (2006) stated that the basic foundation of the religion of Islam is a faith, worship, and morality. Islam is the religion of monotheism brought by Prophet Adam A.S. to the Prophet Muhammad. Tawheed is the essence of faith in God Almighty. Tawheed means the Oneness of Him in worship and not ascribing partners to Him. Tawheed means the Oneness of God, that Allah alone is the only God. Islam has ordered man to keep the universe, one of them by carrying out social responsibility, as in (QS. Al-Imran: 64; Al-Araf: 56)

As the representative of Allah SWT, man has responsibility to maintain, preserve and conserve the entire creation of Allah SWT. Responsibilities, maintain, preserve and keep creation of Allah SWT is an economic accountability in Islam. Accountability is intended to do with the disclosure of a good, honest, fair and transparent. Accountability is not only shown to stakeholders and other stakeholders but also to God as the One of the most high in giving blessings and success (AbuTapanjeh, 2009). In other words, the primary accountability is to God as the Lord of the Worlds.

Accountability in the form of Islam is not merely reporting a material form, but also a broader scope of accountability such as reporting of corporate social responsibility in accordance with Islamic principles. Reports of corporate social responsibility in the conventional system are only focuses on the aspects of material and moral. Haniffa (2002) adds that the report should have social responsibility there must be a spiritual aspect and the primary focus in the reporting of corporate social responsibility.

Therefore, the need is for a special framework for corporate social responsibility reporting in accordance with the principles of Islam. The framework is not only useful for decision-makers Muslims, but also useful to help Islam company in the fulfilment of obligations towards Allah and society. This framework is known as ISR. Sharia principles are the basis of the formation of a comprehensive ISR. Sharia principles in the ISR produce material aspects, moral, and spiritual constituting the main focus of corporate social responsibility reporting. This study uses the ISR framework composed of several studies related to the primary reference on Othman et al. (2009), which consists of six themes of disclosure, namely: (1) Funding and Investment (Finance and Investment). (2) Products and Services (Product and Service). (3) Employees (Employees), (4) Community (Community), (5) Environment (Environment), (6) Corporate Governance (Corporate Governance).

Based on Bapepam-LK regulation No. IX.A.13 of Islamic securities issuance. Sukuk is an Islamic securities in the form of a certificate or proof of ownership of the same value and represent a part's ownership integral or divided over the ownership 
of tangible assets given, the value of benefits and services on asset specific project or activity of certain investments and ownership of the assets of a specific project or activity of certain investments, In this study, the sukuk variable adopt Hossain et.al (2006), comprehensive information should be disclosed when a security is not just about to published, but also for those securities remains one source of funding for the company. Moreover, additional information is also needed as a form of monitoring the bond holders on the use of proceeds from the IPO. As a Muslim investor should determine whether the funds they invested actually used for activities that do not conflict with the principles of Islam.

Company Size is a predictor variable that is widely used to describe various disclosure of corporate social responsibility in the company's annual report. It is if it is associated with agency theory, indicating that large companies that have cost the agency greater will reveal information more widely to reduce agency costs, in addition to the large companies are listed spotlight, greater disclosure is cost reduction politically as a form of corporate social responsibility (Sembiring, 2005). Based on agency theory that it is a positive relationship firm size on the disclosure of ISR, as expressed in the research Sembiring (2005), Anggraini (2006), Yuliana, et. al (2008), Setyorini \& Ishak (2012), as well as Khasharmeh \& Desoky (2013). Some research suggests that the size of the company proved a positive influence on CSR disclosures in annual financial statements such as Sembiring (2005), Setyorini \& Ishak (2012), as well as Khasharmeh \& Desoky (2013) while Anggraini (2006), Yuliana et al. (2008) failed to show a relationship between the two variables is positive.

Profitability is used to assess the company's ability to make a profit and to see the effectiveness of the management of a company to disclose its social responsibility. The higher profitability means that the higher the company's ability to generate profits that will be more extensive disclosures are made company. Agency theory explains that managers of companies with higher profits are likely to make disclosures to the broader goal for personal gain, such as promotions and compensation. Profitability can be measured using a number of ways, such as ROA, ROE, earnings per share, the dividend for the period, profit margins, rate of return, and others. Haniffa $\&$ Cooke (2005) proved that profitability had a significant positive effect on the level of mandatory and voluntary disclosure.

\section{Methods}

This research is a quantitative study using secondary data. The method used in this research is content analysis. It aims to find out how much the level of disclosure 
of the 46 principal disclosure of ISR. Sekaran \& Bougie (2010) explains that the content analysis is observational research methods used systematically to evaluate the content of the symbol of all forms of communication were recorded. Content analysis can be used to analyze newspapers, web sites, advertisements, interview footage, as well as annual reports of companies. Content analysis is to identify the types of disclosures ISR by reading and analyzing the company's annual report. The disclosures type is coded into the coding sheet. Characteristics of the disclosure in the form of words, sentences, pictures, or graphs encoded in accordance with the theme of disclosure. This method has its advantages and disadvantages. The advantage is that this method is the most available to know how big the floodgates disclosure of social responsibility of the company. The disadvantage is researchers have a high level of subjectivity in interpreting the main points of ISR in the coding process.

This research is a quantitative study using secondary data. The data in this study is panel data that annual reports of companies included in the List of Islamic Securities (DES) in Indonesia during the years 2012-2014. List of Islamic Securities is a collection of effects that do not conflict with the principles of Islamic capital market applied by Bapepam LK or party approved by Bapepam LK (per 22 November 2012 has been transformed into the Financial Services Authority).Data collection techniques gained through www.bapepam.go.id sites and www.idx.co, id.

The population in this study are the companies that were included in the list of Islamic securities in Indonesia during the years 2012 - 2014 sample in this study were selected by purposive sampling method, namely by meeting defined characteristics (1) The Company is included in the list of Islamic securities and recorded (listed) on the Stock Exchange during the period 2012-2014. List of Islamic Securities are always updated by Bapepam LK every six months (the period) so that the sample used is the companies included in the list of Islamic securities as much as six periods. (2) Publish complete annual report for the year 2012-2014. (3) Companies that use Rupiah as the unit of currency in the company's annual report. It aims to give equal treatment to all samples so the results are not biased. Based on these criteria obtained a sample of 30 companies.

Data obtained as many as 30 companies and analysed by using multiple regression techniques through assumption test and test hypotheses. To test the hypothesis then created a model that describes the relationship between variables to be studied. Models were prepared using a multiple regression equation as follows:

$$
\operatorname{ISR}_{\mathrm{i}}=\alpha+\beta_{1} \text { DSukuk }_{\mathrm{i}}+\beta_{2} \text { Size }_{\mathrm{i}}+\beta_{3} \text { Profit }_{\mathrm{i}}+\varepsilon_{\mathrm{i}}
$$


Whereas: ISR is Islamic social reporting; Dsukuk is company issued sukuk; Size is the company's size; Profit is the profitability.

\section{Results and Discussion}

\section{Result}

Test for normality in this test using normal graph analysis P P Plot and Kolmogorov-Smirnov Test. Based on the normal graph Plot P-P can be concluded that the normally distributed. Multicolinearity test concluded that there is no multicollinearity between independent variables in the regression model. Heterokedastisitas test conclude the regression model free of heterokedastisitas. Autocorrelation test obtained auto correction value of Durbin Watson (DW) of 2.071. While the lower limit value ( $\mathrm{dl}$ ) of 1.5889 and the upper limit value (du) of 1.7264. Thus, the value of DW is between the value of du and 4-dl $(\mathrm{du}<\mathrm{DW}<4-\mathrm{du})$, so it can be inferred that the regression model used free of autocorrelation.

In this study, the coefficient of determination test is performed to measure the independent variable is the variable of company issuing sukuk, company size and profitability and the dependent variable is Islamic Social Reporting (ISR). The result showed that the coefficient of determination obtained value of adjusted $\mathrm{R}^{2}$ of $.444(44.4 \%)$. This means that $44.4 \%$ of variation ISR disclosure can be affected by the issuance of sukuk, size, and profitability, while $45.6 \%$ ISR disclosure can be affected by other variables not examined in this study as leverage, the type of company.

Testing the hypothesis in this study was conducted using regression analysis model. In this study is using hypothesis testing by means of simultaneous test (F test) and test per variable ( $\mathrm{t}$ test). Simultaneous test ( $\mathrm{F}$ test) was conducted to test whether all the independent variables together in a regression model has an influence on the dependent variable. The results shown ithat the value of $\mathrm{F}=24.678$ with a significance of .000 less than .05 . Then Ho is accepted, meaning together (simultaneously) no influence sukuk issuance, company size, and profitability, on the disclosure of ISR enterprise.

The $\mathrm{t}$ test aims to determine whether the independent variable partially significant effect on the dependent variable and to further examine which of the independent variables that affect the disclosure of ISR. The t-test results can be shown in Table 1. Variable issuance of sukuk has a t-value 0.694 . This means the first hypothesis is rejected, which means that the variable sukuk issuance does not affect the company's ISR disclosure. Thus, the company that issued sukuk positive 
effect on the disclosure of ISR is rejected. Furthermore, the size of variables affect the disclosure of ISR. Thus, the second hypothesis is that the size of the company positive effect on the disclosure of ISR is accepted. Variable profitability has $t$ value of 0.193 . This means third hypothesis is rejected, meaning that partially it can be concluded that the profitability variable does not affect the disclosure of ISR. Thus, the third hypothesis Profitability positive effect on the disclosure of ISR is rejected.

Table 1 t-test Result

Coefficients $^{\mathrm{a}}$

\begin{tabular}{lrrrrrrrr}
\hline \multicolumn{1}{c}{ Model } & \multicolumn{2}{c}{$\begin{array}{c}\text { Unstandardized } \\
\text { Coefficients }\end{array}$} & \multicolumn{1}{c}{$\begin{array}{c}\text { Standardized } \\
\text { Coefficients }\end{array}$} & \multicolumn{1}{c}{ t } & Sig. & \multicolumn{3}{c}{$\begin{array}{c}\text { Collinearity } \\
\text { Statistics }\end{array}$} \\
& \multicolumn{1}{c}{ B Error } & Beta & & & Tolerance & VIF \\
\hline (Constant) & -37.716 & 7.199 & & -5.239 & .000 & & \\
Dsukuk & 1.746 & 2.516 & .055 & .694 & .490 & .986 & 1.015 \\
Size & 2.090 & .247 & .674 & 8.472 & .000 & .988 & 1.012 \\
Profit & .963 & 4.979 & .015 & .193 & .847 & .981 & 1.020 \\
\hline
\end{tabular}

a. Dependent Variable: y_isr

Source: SPSS Output processed

The results of multiple regression equation showed that all variables have positive coefficients. This means that the increase in the value of all variables will increase the company's disclosure of ISR. The regression coefficient sukuk issuances amounting to 1.746 means that if the value of another independent variable value is fixed and sukuk rose 1\%, the disclosure of ISR increased by 1.746 activities. The regression coefficient variable size of 2.090 means that if another independent variable value is fixed and the size increased 1\%, the disclosure of ISR increased by 2.090 activities. Profitability variable regression coefficient of .963 means that if another independent variable value is fixed and profitability rose $1 \%$, the disclosure of ISR increased by .963 activities.

\section{Discussion}

The first hypothesis in this study is the company issuing the sukuk positive effect on the disclosure of ISR. These results indicate that the first hypothesis stating that the company issuing the sukuk positive effect on the disclosure of ISR rejected. One objective of the company is largely determined by the structure of ownership. 
The owners will always try to make a strategy to achieve corporate objectives. The ownership structure can be explained through two approaches, namely the agency and information asymmetry approach. According to the agency approach the ownership structure is a mechanism to reduce conflicts of interest between managers and shareholders. While the information asymmetry approach considers that the ownership structure as a way of reducing the information asymmetry between insiders and outsiders through information disclosure in capital markets (Jensen $\&$ Meckling, 1976).

The results in this study show that the first hypothesis is rejected because of the ownership structure of companies in Asia, including in Indonesia tend to family ownership concentration ownership structure of companies in Asia, including in Indonesia tend to family ownership concentration. The ownership structure of an impact is on the characteristics of corporate funding. So the company whose ownership lies in the majority of families are not compelled to perform high transparency because there is no guidance from outsiders (Claessens \& Fan, 2002). This contrasts with Hossain et.al (2006)which proves that the issuance of the bonds have an influence on voluntary disclosure.

The second hypothesis states that the size of the company positive effect on the disclosure of ISR. These result indicates that the second hypothesis which states that the size of the company positive effect on the disclosure of ISR is accepted. The size of the company can measure by the total assets. In general, large companies will disclose more information than smaller companies. These results indicate that the variable size of the company determines the disclosure of ISR, The larger the company, the more ISR disclosed. In addition, large companies are listed spotlight; greater disclosure is the reduction of the cost of political as a form of corporate social responsibility. Larger companies certainly have the resources, facilities and human resources more than the smaller companies. Specifically, the larger the size of the company's sharia, increasingly also stakeholders Muslim influence or be influenced by the company's business activities. Thus the company greater sharia would tend to make social responsibility disclosure by sharia wider than the smaller companies. This study was supported by research (Othman et al., 2009; Hossain \& Hammami, 2009).

The third hypothesis stated that the positive affect on the profitability of the disclosure of ISR. These result suggests that the third hypothesis which states that the positive effect on the profitability of the disclosure ISR is rejected. Based on agency theory that the greater the profit that would make companies disclosure social information more widely. In this study showed that the level of profitability does not affect disclosure CSR. This influenced by the perspective 
associated with the company dualism CSR relationships with profits in CSR. Most companies look at that view CSR as a deduction from income, and there is also a contrary view Capaldi (2006) in Yuliana et al. (2008). This is in line with research Hossain et.al (2006) who found that profitability has no influence on the disclosure of the company's annual report. These results were confirmed by Haniffa (2002) that in the view of Islam, which the company has the intention to conduct ISR disclosure will not consider whether the condition of profit or loss.

\section{Conclusion}

The results of this study concluded that the company issuing the sukuk has no effect on the disclosure of ISR, because that the ownership structure of companies in Indonesia tend to family ownership concentration, so the company whose ownership the majority located on the family and the banks tend not compelled to perform high transparency because there is no guidance from external parties. The results of this study are inconsistent with Hossain et.al (2006) which proves that the issuances of the bonds have an influence on voluntary disclosure. Whereas, the second one is the size of the company's influence is on the disclosure of ISR. This indicates that the variable size of the company is crucial in the disclosure of ISR, The larger the company, the more ISR disclosed. In addition, large companies are listed spotlight; greater disclosure is the reduction of the cost of political as a form of corporate social responsibility. The results of this study are consistent with research Othman et al. (2009) and Hossain \& Hammami (2009) while the profitability variable does not affect the disclosure of ISR. It is influenced by the company's perspective on corporate social responsibility (CSR); most companies look at that view CSR as profit used and also the view instead. The results of this study are consistent with Hossain et.al (2006) who found that profitability has no influence on the disclosure of the company's annual report.

\section{References}

Abu-Tapanjeh, A. M. (2009). Corporate governance from the Islamic perspective: A comparative analysis with OECD principles. Critical Perspectives on Accounting, Vol. 20 (5): 556-567.

Anggraini, F. R. R. (2006). Pengungkapan Informasi Sosial dan Faktor-Faktor yang Mempengaruhi Pengungkapan Informasi Sosial dalam Laporan Keuangan Tahunan ( Studi Empiris pada Perusahaan-Perusahaan yang terdaftar Bursa Efek Jakarta ). In Simposium Nasional Akuntansi 9 Padang (pp. 23-26). 
Claessens, S. \& J.P.H. Fan. (2002). Corporate Governance in Asia : A Survey. International Review of Finance, Vol. 3 (2): 71-103.

Freeman, R.E. \& J.M. Vea. (2001). A Stakeholder Approach to Strategi Management. Working Paper, 01-01: 1-32.

Haniffa, R. (2002). Social Reporting Disclosure: An Islamic Perspective. Indonesian Management \& Accounting Research. Vol. 1 (2): 128-146.

Haniffa, R. M. \& T.E. Cooke. (2005). The impact of culture and governance on corporate social reporting. Journal of Accounting and Public Policy, Vol. 24: $391-430$.

Hossain, M.. et.al. (2006). Corporate Social and Environmental Disclosure in Developing Countries: Evidence from Bangladesh. Procedings of the Asian Pacific Conference on International Accounting Issues. Hawaii.

Hossain, M., \& H. Hammami, H. (2009). Advances in Accounting, incorporating Advances in International Accounting Voluntary disclosure in the annual reports of an emerging country: The case of Qatar. International Journal of Cardiology. Vol. 25(2): 255-265.

Jensen, M. C. \& W. Meckling. (1976). Theory of the Firm: Managerial Behaviour, Agency Costs y Ownership Structure. Journal of Financial Economics. Vol. 3(4): 305-360.

Khasharmeh, H.A. \& A.M. Desoky. (2013). On-line Corporate Social Responsibility Disclosures : The Case of the Gulf Cooperation Council ( GCC ) Countries. Global Review of Accounting and Finance. Vol. 4 (2): 39-64.

O’Donovan, G. (2015). Environmental Disclosures in the annual Repot: Extending the applicabillity and Predictive Power of Legitimay Theory. Report Information from Proquest, (March): 14-17.

Othman, R. et.al. (2009). Determinants of Islamic Social Reporting Among Top Shariah -Approved Companies in Bursa Malaysia. Research Journal of International Studies. Vol. 12 (12): 4-20.

Sekaran, U. \& R. Bougie. (2010). Research Methods For Business: A Skill Building Approach. New Jersey: John Wiley \& Sons, Ins.

Sembiring, E. R. (2005). Karakteristik Perusahaan dan Pengungkapan Tanggung Jawab Sosial: Study Empiris pada Perusahaan Yang tercatat di Bursa Efek Jakarta. In Simposium Nasional Akuntansi 8 (pp. 379-395).

Setyorini, C. T. \& Z. Ishak. (2012). Corporate Social and Environmental Disclosure : A Positive Accounting Theory View Point. Internatioanl Journal of Business and Social Science. Vol. 3 (9): 152-164. 
Al-Iqtishad: Jurnal Ilmu Ekonomi Syariah (Journal of Islamic Economics) Vol. 9 (1), January 2017

Triyuwono, I. (2012). Akuntansi Syariah: Perspektif, Metodologi, dan Teori (Edisi Kedua). Jakarta: Rajawali Press.

Yuliana, R. et.al. (2008). Pengaruh Karakteristik Perusahaan Terhadap pengungkapan Corporate Social Responsibility (CSR) dan Dampaknya terhadap Reaksi Investor. Akuntansi Dan Keuangan Indonesia. Vol. 5 (2): 246-276. 